\begin{tabular}{|c|c|}
\hline $\begin{array}{l}\text { Proceedings of the Institution of } \\
\text { Civil Engineers } \\
\text { Municipal Engineer } 163 \\
\text { March } 2010 \text { Issue MEI } \\
\text { Pages } 23-31 \\
\text { doi: } 10.1680 \text { /muen.20I0.163.1.23 }\end{array}$ & $\begin{array}{l}\text { Ana Faggi } \\
\text { Senior Lecturer, School } \\
\text { of Ecological } \\
\text { Engineering, Macn- }\end{array}$ \\
\hline $\begin{array}{l}\text { Paper 800026 } \\
\text { Received 03/04/2008 } \\
\text { Accepted 14/04/2009 }\end{array}$ & $\begin{array}{l}\text { Buenos Aires; } \\
\text { Argentina }\end{array}$ \\
\hline $\begin{array}{l}\text { Keywords: } \\
\text { management/ports, docks \& } \\
\text { harbours/urban regeneration }\end{array}$ & \\
\hline
\end{tabular}

\title{
Renewal of Buenos Aires city waterfront
}

\section{A. Faggi PhD}

This paper reports an analysis of the main phases and factors relevant to the renovation of the coastal area of the city of Buenos Aires. Since the early 1980s, and especially with the country's comeback of democratic life, that area developed along two different paths. The renovation of the docks followed a top-down process carried out by private-public enterprises; it was a successful and lucrative real-state transformation in which contemporary design and aesthetics had precedence. The ecological restructuring of the river front was, however, the outcome of a bottom-up process that involved many actors with conflicting interests quarrelling during two decades. Thanks to the non-government organisation 'Ciudad', who enabled the involvement of otherwise excluded social groups and had ample communitarian support behind its initiatives; the renovation of the coastal strip was successful. The ideologies and policies that have shaped this effort over the years are also discussed in this report.

\section{INTRODUCTION}

Especially since the beginning of the 1990s, urban and territorial structures in Latin America have changed substantially with new localisation of the centres and redistribution of private and public spheres. Sprawling cities, favoured by private transportation, have spread all over the continent.

In recent decades Argentina has undergone an intensive urbanisation process. More than $80 \%$ of its 37 million inhabitants live in cities.

By the 1990s Buenos Aires experienced important socioterritorial transformations (Torres, 2001), including more urban landscapes, a loss of public spheres and habit changes (Janoschka, 2002). In addition, the urban coast underwent a reorientation from port and transportation uses to commercial, residential and recreational areas. Urban conglomerates such as Buenos Aires and many neighbouring localities in the metropolitan area experienced the reshaping of waterfronts as a catalyst for urban regeneration (Busquets, 1995), which also occurred in smaller cities such as Ushuaia, and some other inland riverine cities such as Rosario, Paraná and Neuquén.

The urban waterfront redevelopment is an ongoing phenomenon that started in the 1970s in Baltimore harbour and has gradually spread to other cities such as Amsterdam, Barcelona, Boston, Cape Town, Cardiff, Copenhagen, Duisburg, Frankfurt, Genoa, Hamburg, Helsinki, Hong Kong, Lisbon, London, Liverpool, Melbourne, Oslo, Rotterdam, Shanghai, Sydney and Vancouver among others (Gospodini, 2006). They are concrete cases where waterfront development started the mechanisms of change that made them able to compete at either the international or the regional scale.

The waterfront, where the city meets the river or the sea, is the edge between the urban structure and the spontaneous vegetation. Its redevelopment comprises the historic alteration of land and water uses along the edges of cities throughout the world (Sairinen and Kumpulainen, 2006).

Cities are products of history and are therefore socially conditioned. Their waterfront areas and associated costal strips have become true laboratories for the experimentation of the new space structures for the global city.

Waterfronts are complex locations in which to study transformative processes (Bunce and Desfor, 2007). Trends in the regeneration of waterfronts indicate greater collaboration in planning and design between architects and engineers as the revitalisation grows increasingly sophisticated (Mann, 1988).

The present paper discusses the process of redeveloping the Buenos Aires waterfront, paying special attention to the ecological renovation of the river banks. This process is considered as a good and representative example for other cities in developing countries, which are also experiencing a rapid growth. The aim of the paper is to highlight the influence of civil commitments and public participation in solving environmental problems and shaping policies for sustainable urban forms.

\section{ANALYTICAL FRAMEWORK}

Ecological urban restructuring is the central challenge of the twenty-first century. The environmental crisis of cities is intimately related to the evolution of the industrial society; Agenda 21 stated the need for an urgent rethinking of urban planning.

Ecological urban restructuring succeeds when problems have been solved by different stakeholders' networks. This alliance guarantees better economic effectiveness, ecological efficiency and social acceptance of the changes that are being proposed. 
The need in facing a common challenge is for knowledge and experience to overcome old structures by consensus, as stated in chapter 28.3 of the local Agenda 21 (www.un.org/esa/sustdev/ agenda21.htm). This new form of co-operative work involves, for example, residents, the local government, non-governmental organisations (NGOs), academia and businesspersons.

Coastal areas are rather fragile from an ecological point of view. They are also extremely conflict-prone because of many specific interests that influence their use: harbour and transport facilities, landholders, sport clubs and associations, green-area user groups and diverse governmental agencies, to name a few. Coastal areas are therefore very well suited to develop participatory management approaches such as adaptive co-management. The physical diversity and the multiple needs make design a challenge and an opportunity (Sairinen and Kumpulainen, 2006).

Adaptive co-management emphasises that learning is always by doing (Walters and Holling, 1990). Its objectives can be treated as 'experiments' from which people can learn by testing and evaluating different management policies (Walters, 1997). This strategy is tailored to specific places and situations are supported by various organisations at different levels in society (Olsson et al., 2004).

The management of the coast, including rivers and their watersheds, depends on collaboration across political, administrative and ownership boundaries (Brody et al., 2004), because it is linked more to ecological systems than to administratively defined boundaries.

Coastal areas usually show high population growth rates as well as the most complex environmental problems (Yanez-Arancibia and Day, 2004). They therefore have a strong need for restoration programmes, that public pressure can help to draft as a strong environmental plan and also ensure that those programmes are implemented (Brody et al. 2004).

According to the Society of Ecological Restoration, ecological restoration is the process of assisting the recovery and management of ecological integrity (http://www.ser.org/ definitions.html).

Most restoration ecologists have a tendency to see their jobs as only technical (van Diggelen et al., 2001), but good restoration requires the inclusion of historical, cultural, political and moral aspects (Higgs, 1997). The support from other groups of society is essential for success and should be integrated into social and technical mechanisms of land use decision making (Pfadenhauer, 2001). Moreover environmental administrators and engineers need to have the ability to promote public understanding of the reasons for specific decisions (Wang and Fang, 2000).

An alternative approach to management or restoration of coastal ecosystems emerges if one accepts that they are open and dynamic and that humans are a crucial part of the ecosystem (Richardson et al. 2007).

\section{COAST OF BUENOS AIRES}

The city of Buenos Aires ( $34^{\circ} 36^{\prime} \mathrm{S}$ and $58^{\circ} 26^{\prime} \mathrm{W}$ ) is the capital of Argentine. It extends over $202 \mathrm{~km}^{2}$, with a population of approximately 3 million people. Including the metropolitan area, with the natural borders of two rivers (La Plata and Riachuelo) to the east and south, it has more than 10 million inhabitants and it ranks third among the ten most populated urban conglomerates in the world.

The relationship between the city and the estuary's waterfront has been in the past very particular and conflicting (Figure 1). A common saying 'Buenos Aires grew turning its back to the river' describes physically and metaphorically the historical relationship between city and riverside.

The coast was developed into a harbour and a warehouse area for international maritime shipping and was predominantly inaccessible to the public.

In 1918 a municipal resort gave direct access to the coast, and its beaches became very popular. During the 1920s and 1930s the resort became one of the favourite promenades all through the day. Many restaurants and vaudevilles were opened in the 1940s and the 1950s, but since 1960 the seaside's appeal has declined because swimming was forbidden owing to severe river contamination.

In the 1970s, during the military government, access to the whole periphery of the shoreline was forbidden to the public.

Part of the coast was land-filled to create green areas; the construction of a 'Government Buildings Area' using the Dutch 'polder' system was started in 1978.

A few blocks away from downtown, embankments were built with demolition materials brought from highway construction works. The polders were filled with silt and sand from the river and drained. However, this work was not completed, and it was finally abandoned in 1984. The 353 ha reclaimed from the river were very soon spontaneously colonised by riverine-forests, grasslands, scrublands and wetlands. The new landscape offered shelter and food to many bird species and other animals (Figure 2).

By the early 1980s the lagoons and grasslands attracted the attention of bird watchers and the place also became a meeting point for joggers, cyclists, students and naturalists. In 1986, the city council granted protection to the area in response to claims from many local NGOs. Since 2005 the natural reserve 'Costanera Sur' has been included in the Ramsar list of important wetlands (www.ramsar.org).

After democracy returned (1984), governmental perceptions of the dockland area began to change. Some speculative investors saw the chance of making money through the development of multi-storey buildings in that under-valued area (Aguilar et al., 2005).

By the 1990s the improvement of this area became a priority for city leaders and real-estate agents. Therefore, the city council developed a plan to revitalise the waterfront into a centre for performing cultural, leisure and entrepreneurial activities. The old docks and the warehouses in the harbour were redesigned as apartments, cafes, restaurants, a university and art galleries. This 


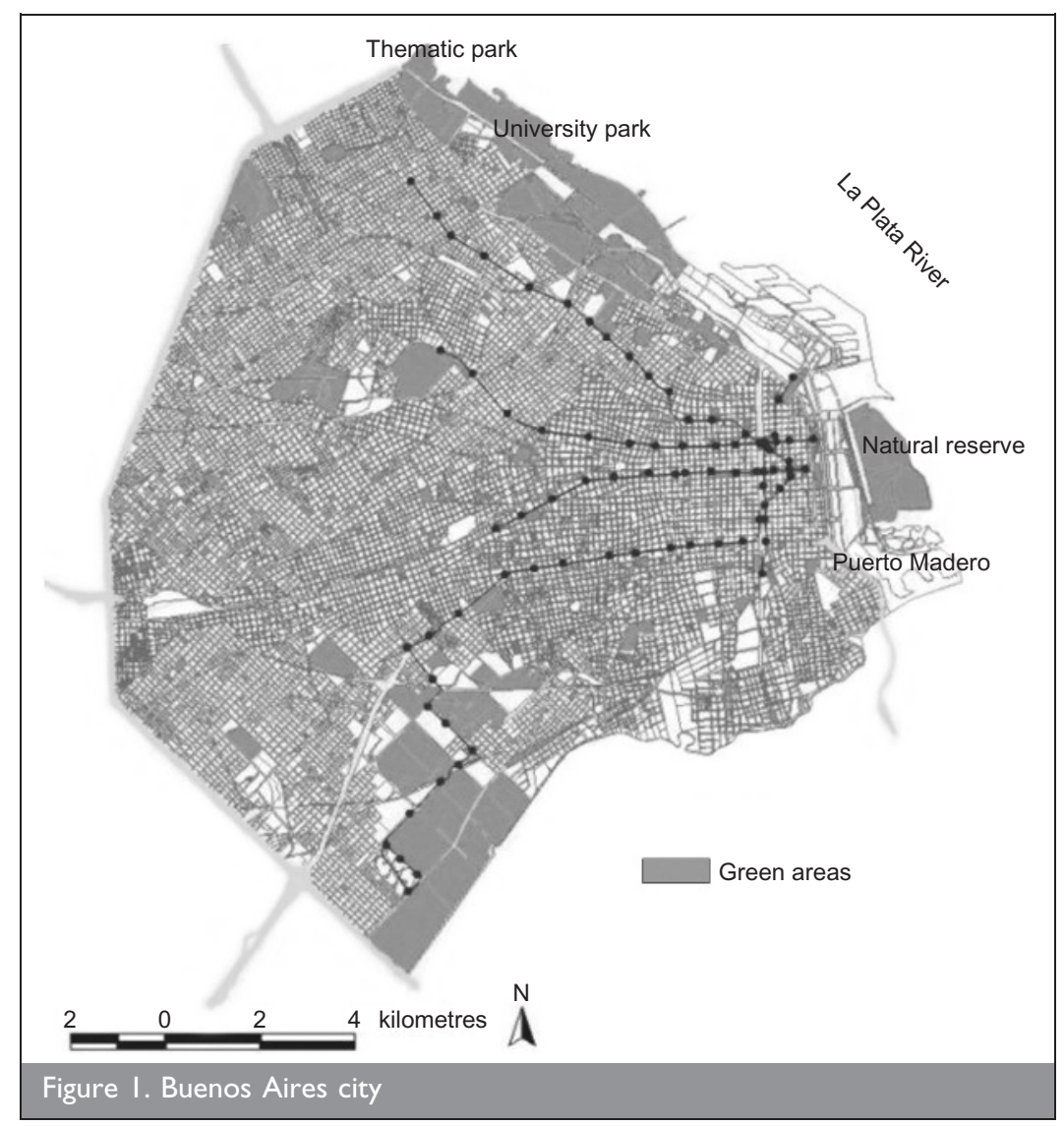

new part of the town is presently known as 'Puerto Madero'. At the moment it is the most fashionable and expensive area of the city, and represents the latest architectural trend in Buenos Aires (Figure 3).

Since 1992 the debate between environmental sustainability and economic development has become more relevant. Many 'green groups' saw the expansion of Puerto Madero as a threat to the preservation of the coast, particularly because there have been many private attempts - supported by the liberal policies of the 1990s - to build to the coastal areas and to reduce the public access.

For the government the pull from economic development was much stronger than that from ecological issues because economic step-up had put increasing welfare per capita at the forefront. Many citizens agreed with these policies, because they improved living standards; they did not care very much about public space and ecological issues in an unsustainable city such as Buenos Aires.

However, a strong environmental movement, inspired by the Agenda 21 (RIO 1992), has rejected the privatisation of the coast; the role of NGOs in collaborative planning to promote urban sustainable development went on.

\section{APPROACHING DECISIONS BY CONSENSUS}

An NGO from the city of Buenos Aires ('Fundación Ciudad') was

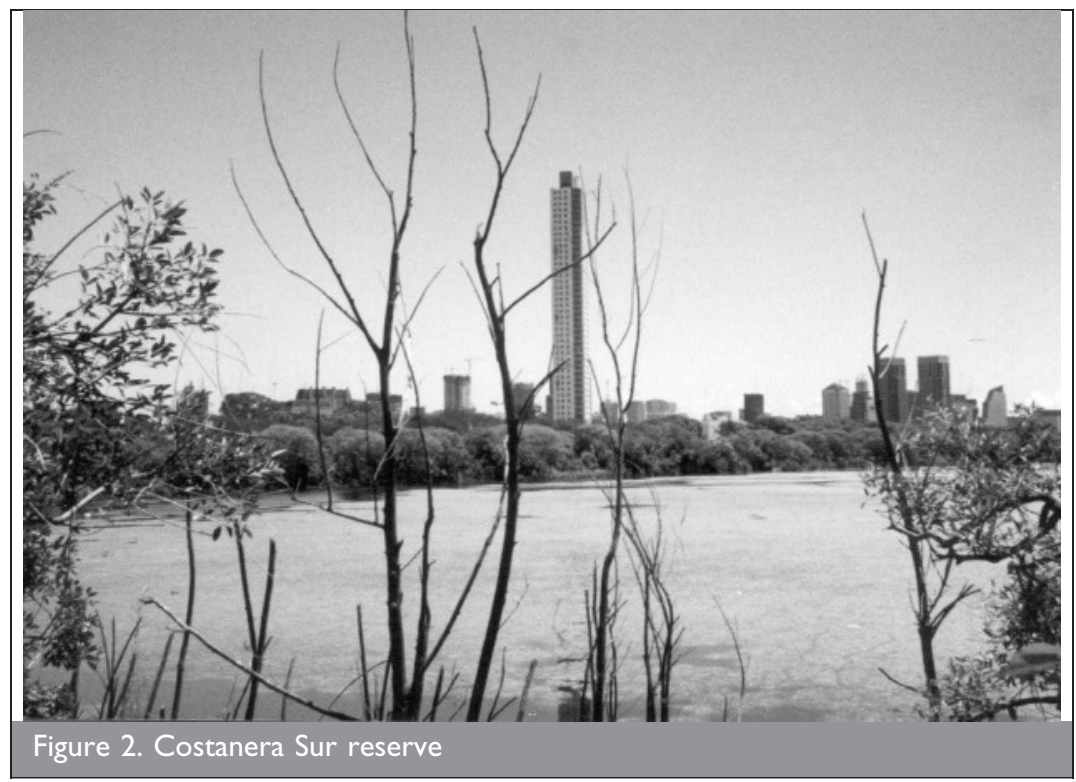




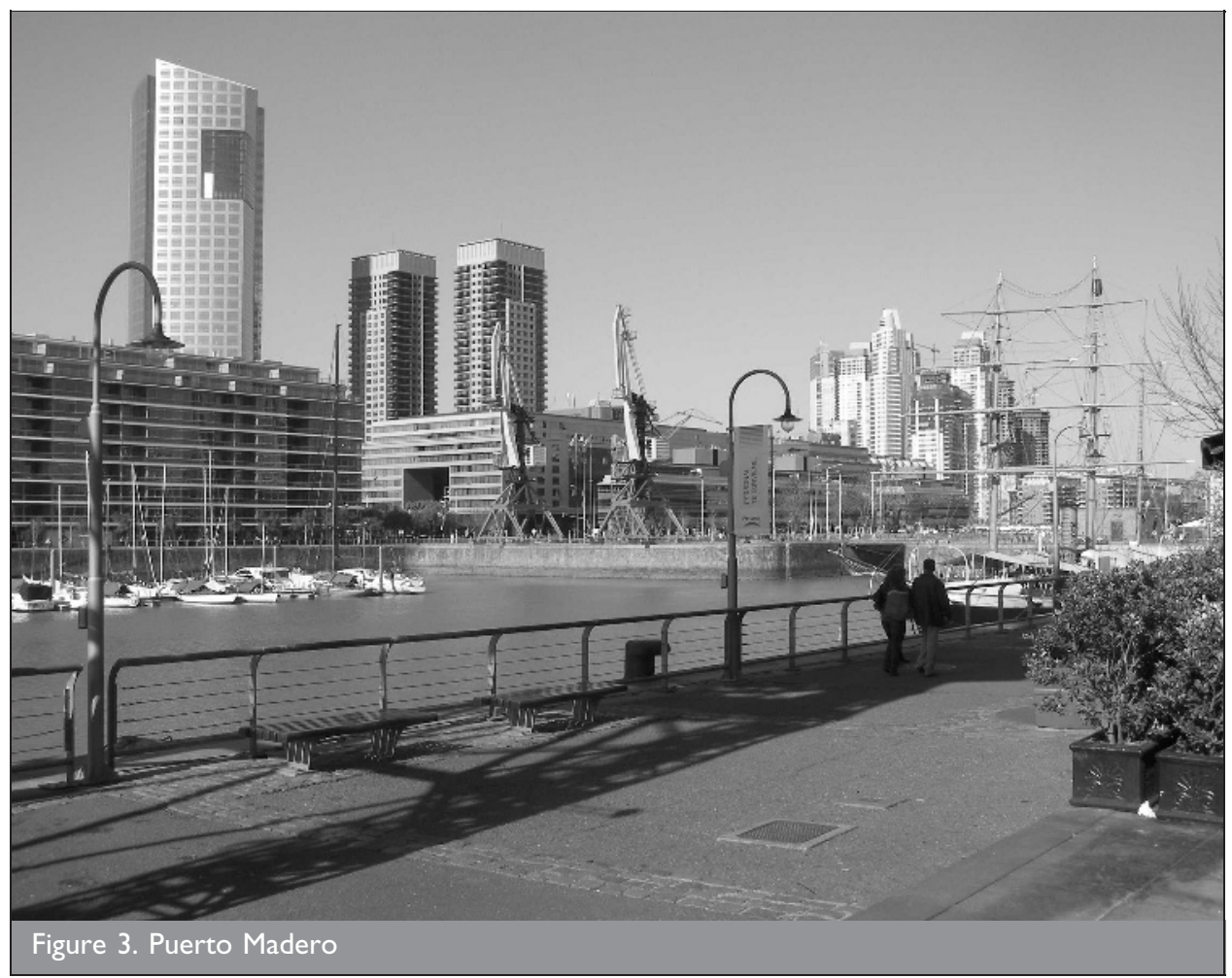

responsible for starting the process to reclaim the coast as a public space (www.fundacionciudad.org.ar).

Since 1998 that NGO has been actively involved on the planning and management of the coastal strip and other relevant issues (Fundación Ciudad, 2007). It has organised many workshops called 'City and River' (1995, 1997 and 1998) - with the aim of encouraging participants to analyse and discuss specific coastal issues. The bottom-up approach used had the objectives, structure and outcomes shown in Figure 4.

A ‘top-down' planning is centralised decision making originated from political and administrative leaders. If, however, the decision is made by residents, the planning enforcement is called 'bottom-up' (Wang and Fang, 2000), or 'co-management', (Lane, 2001). Co-management promotes responsible citizens,

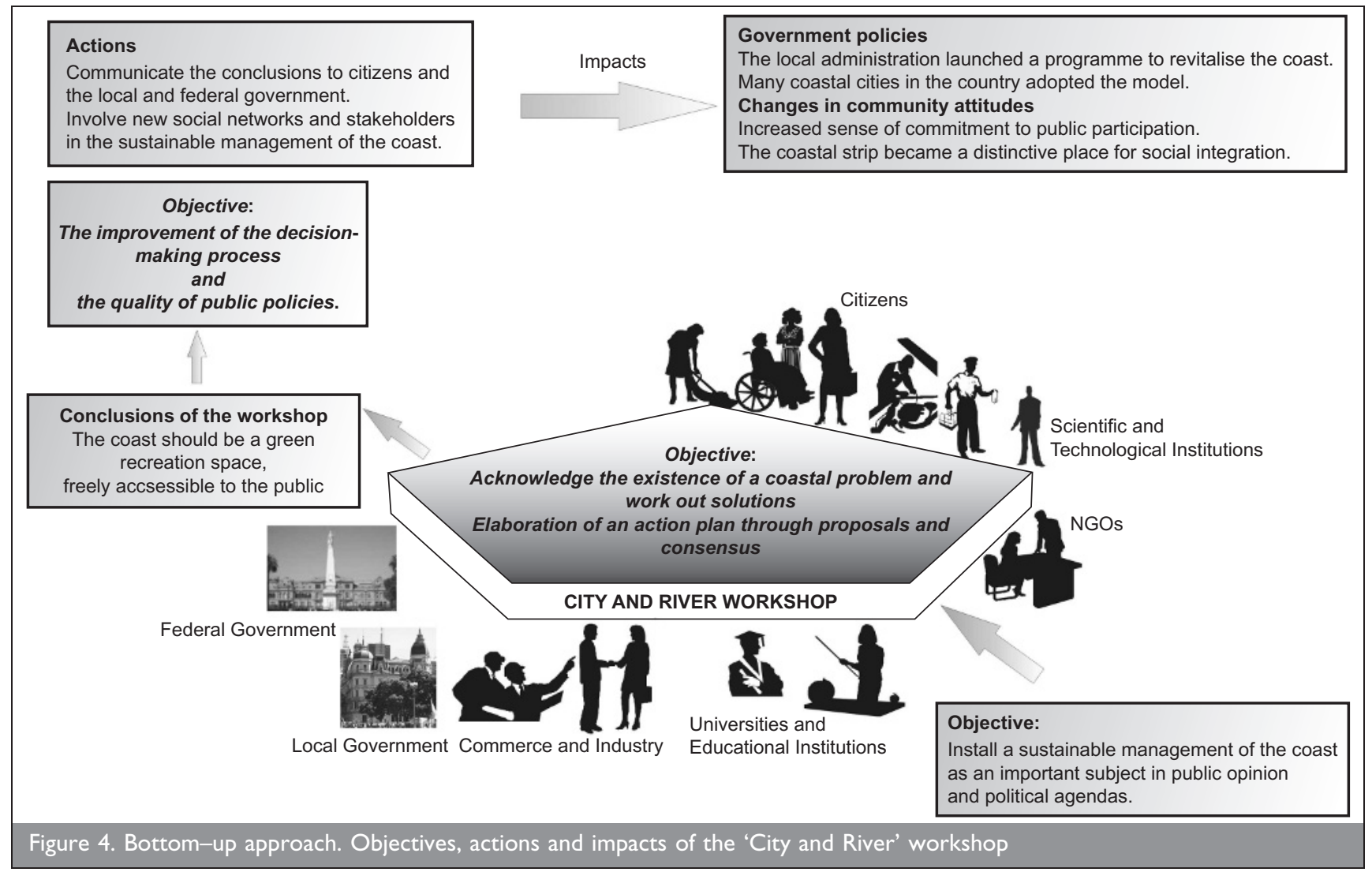


enables a more credible decision-making process and prevents conflicts (Brown and Harris, 2005).

This approach allowed workshop participants from all levels of society to better recognise the coastal problem and thus work out a solution for it.

Through building consensus and resolving conflicts the workshop participants decided that the coast should be a freely accessible public space. Green spaces should be given preference over other spaces, and should only be used for recreation. To obtain the support of politicians the consensus reached and the conclusions of the discussions held were submitted to the national Senate. The foregoing participative process is depicted in Figure 5. It shows how neighbours and NGOs - representing grassroots at the local level -could build the trust and share the understanding needed to mobilise other actors (media, district officials, local and national politicians) at higher institutional levels - for example city and national (Senate) - to achieve concrete environmental policies.

As a result of this strategy the coast became included in the political agenda and the programme 'Buenos Aires and the River' was started.

\section{5. 'BUENOS AIRES AND THE RIVER' PROGRAMME}

As a strategy to circumvent the traditional bureaucracy, a multistakeholder working group was convened to implement the integrated approach. It was composed by people from the city's Environmental Department, NG0s, communal council and university professors (Figure 6). Their meetings were scheduled monthly; members worked pro-bono, except district officials.

During 2004-2006 the group intensively worked and developed concepts for planning and management; it produced three projects located directly on the waterfront with the aim of improving the environmental conditions

(a) restoration of 18 ha in the natural reserve (Figure 7)

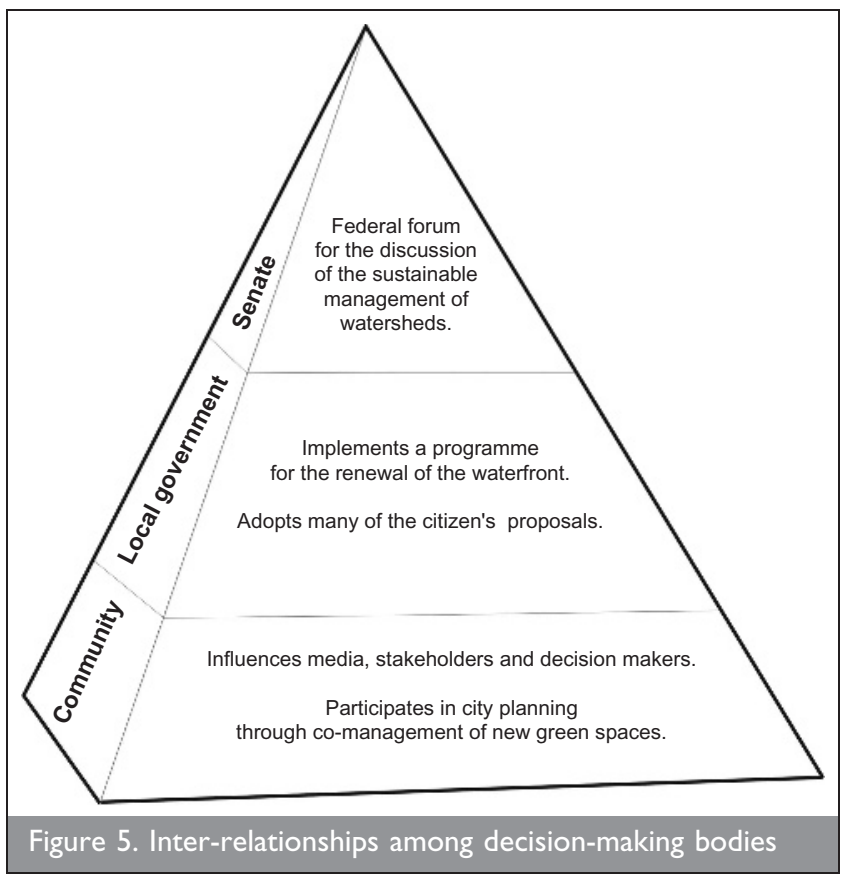

(b) planning of a theme park (17 ha) (Figure 8)

(c) conservation of a forest sector in an university park.

\section{I. The reserve of Costanera Sur}

The reserve has environmental importance and central location. It was the first area to experience the restoration planning by co-management. The idea was simple but beneficial in many ways. The aim was to restore 18 ha, creating many terraces and plains, which reproduced the local geomorphology pre-urbanisation. During 2005-2006, $40000 \mathrm{~m}^{3}$ of earth brought from new subway works were thrown upon a brownfield site. Afterwards the landscape was forested with about 1500 trees (Figure 7).

This new area will provide a continuous pedestrian and cycle pathway along the waterfront and launch different recreation and educational opportunities. At the same time the created terraces (14 m high) will allow visitors to enjoy scenic views of the estuary, the vegetation and the city.

\subsection{Theme park}

Seventeen hectares of man-made landfills along the northeastern edge of the estuary are $8 \mathrm{~km}$ close but disconnected to town. The Environmental City Department recognised its potential as a biodiversity spot because a variety of interesting plant communities had spontaneously covered the whole area. Through the collaborative planning design, the working group decided that this area should become a theme park and be devoted to awaken the public conscience in order to preserve the water quality of the La Plata estuary (Figure 8).

Plans for this area include the definition of trails, some parking facilities and the extension of the public transportation to enhance the connectivity of the isolated area.

\subsection{University park}

The University park is situated in the north-eastern sector of the waterfront and includes mixed forests, wetlands and grasslands. Plans for this area intend to connect a neighbouring public park, the definition of new trails and educational programmes.

\section{DISCUSSION}

Cities can mainly be seen as a result of the local actions of individual households, institutions and civic arrangements. Only in more recent years, has the analysis of urban regeneration recognised that the distinction between the natural and the social is an arbitrary division and that urban life needs to be understood in terms of intertwining social and ecological processes (Cowell and Thomas, 2002).

In Buenos Aires, the perspectives of a coast revival are being adopted in different and contrasting policies. The experience shows that global tendencies of city revitalisation on one side and citizen groups, NGOs and individuals on the other side, have been the driving forces impelling the urban and ecological renewal of the coast of Buenos Aires.

As in other examples (Jaunhianen, 1995) the waterfront renewal has brought huge social, environmental and economic benefits.

As in many cities of the world (Sairinen and Kumpulainen, 


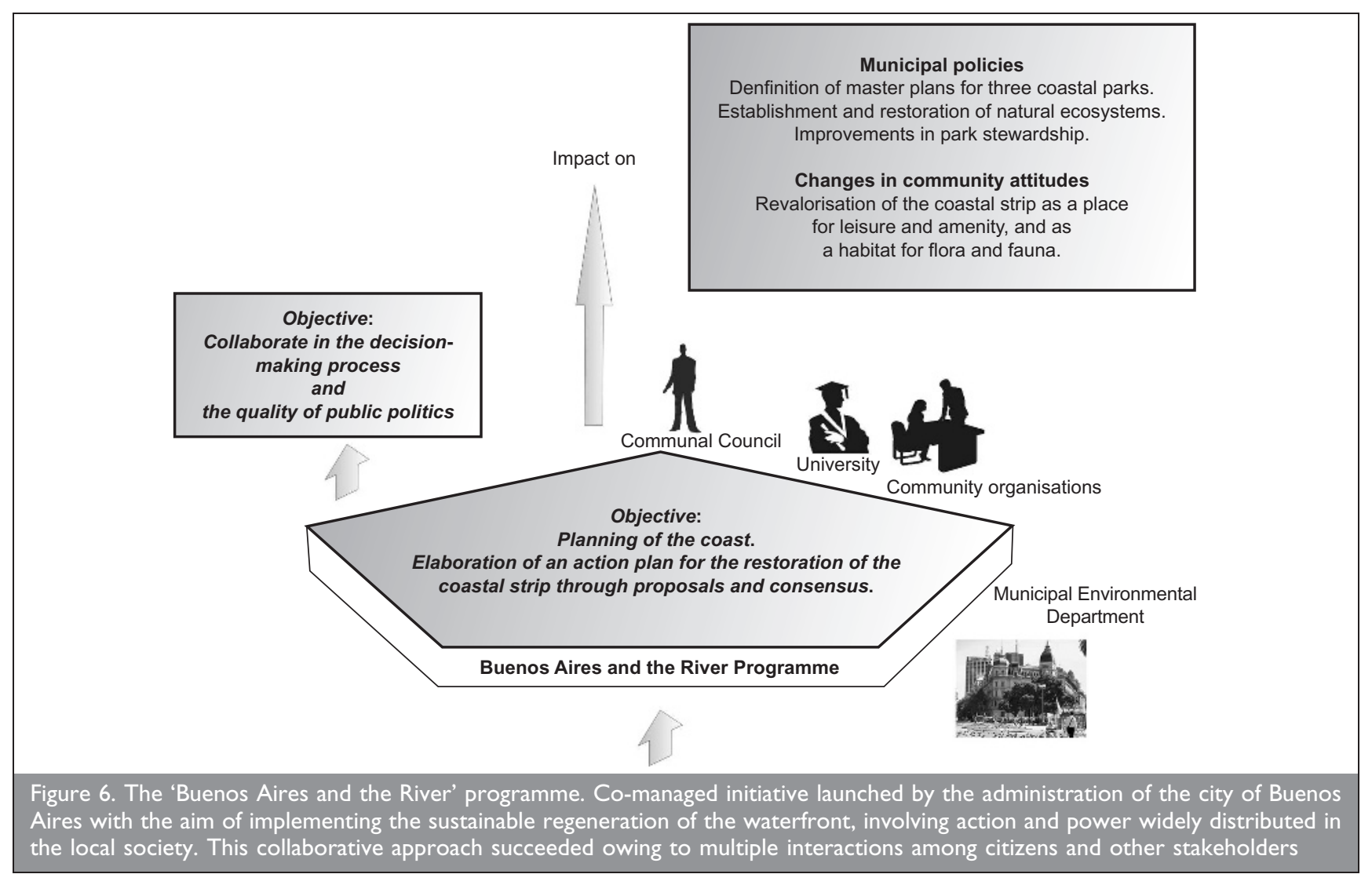

2006), the renewal of the built-up waterfront in Buenos Aires was a top-down process associated with private public enterprises.

Since the 1960s 'top-down' planning as a rational model has been criticised, because it could ignore interests of other stakeholders, cause discontent between citizens and planning authorities and lead to conflicts between the community and managers (Brown and Harris, 2005).

The renewal of the docks was guaranteed by a successful and lucrative real-estate transformation by putting priority on contemporary design and aesthetics. The ecological restructuring of the river front, however, resulted in a bottom-up process that involved many actors and struggles among conflicting interests during two decades.

This process implied a decision making that came from community members without official positions. In this regard it is a good example of a democratic process that common people could start. It became a success because their decisions at the end have been accepted and carried out by centralised agencies.

The coastal strip, reclaimed for the public, now has a free access and is recovering the glory lost in the last four decades. This was a process initiated by local citizens' initiatives, environmental organisations and motivated individuals inspired by the ecological thoughts of the 1990s; they imagined a coast for recreation and the enjoyment of all social sectors. This concept has finally been accepted and received the support of the local government so that a collaborative planning programme could begin. Because of this impetus the local government included the initiative in its political agenda, and assumed a leading role by organising and coordinating the renewal process.

The regeneration turned into a more comprehensive form of policy and practice, introducing ideas of environmental sustainability and community targets (Sairinen and Kumpulainen, 2005).

The case of Buenos Aires shows that community involvement and the development of local strategic partnerships can achieve many environmental goals.

Thanks to the NGO 'Ciudad', who enabled the involvement of otherwise excluded groups and gathered the strength of the community behind initiatives, the restoration of the coastal strip was successful (Krellenberg et al. 2005).

Buenos Aires case differs from many examples of other cities such as Helsinki (Sairinen and Kumpulainen, 2006), Genoa (McCarthy, 2003) and Rotterdam (McCarthy, 2002). The regeneration planning for these cities has been carried out by the administration and social and environmental aspects considered at the very beginning.

In the current case, the renewal of the coast confirmed that voluntary community involvement can start the process of solving management problems of local public areas. Only if civil organisations can be linked to effective local authorities, can the synergistic benefits for such voluntary efforts continue.

The experience of the current author is consistent with other authors (Kennedy et al., 2000; Innes, 1996), who found that environmental problems can be solved by consensus building 


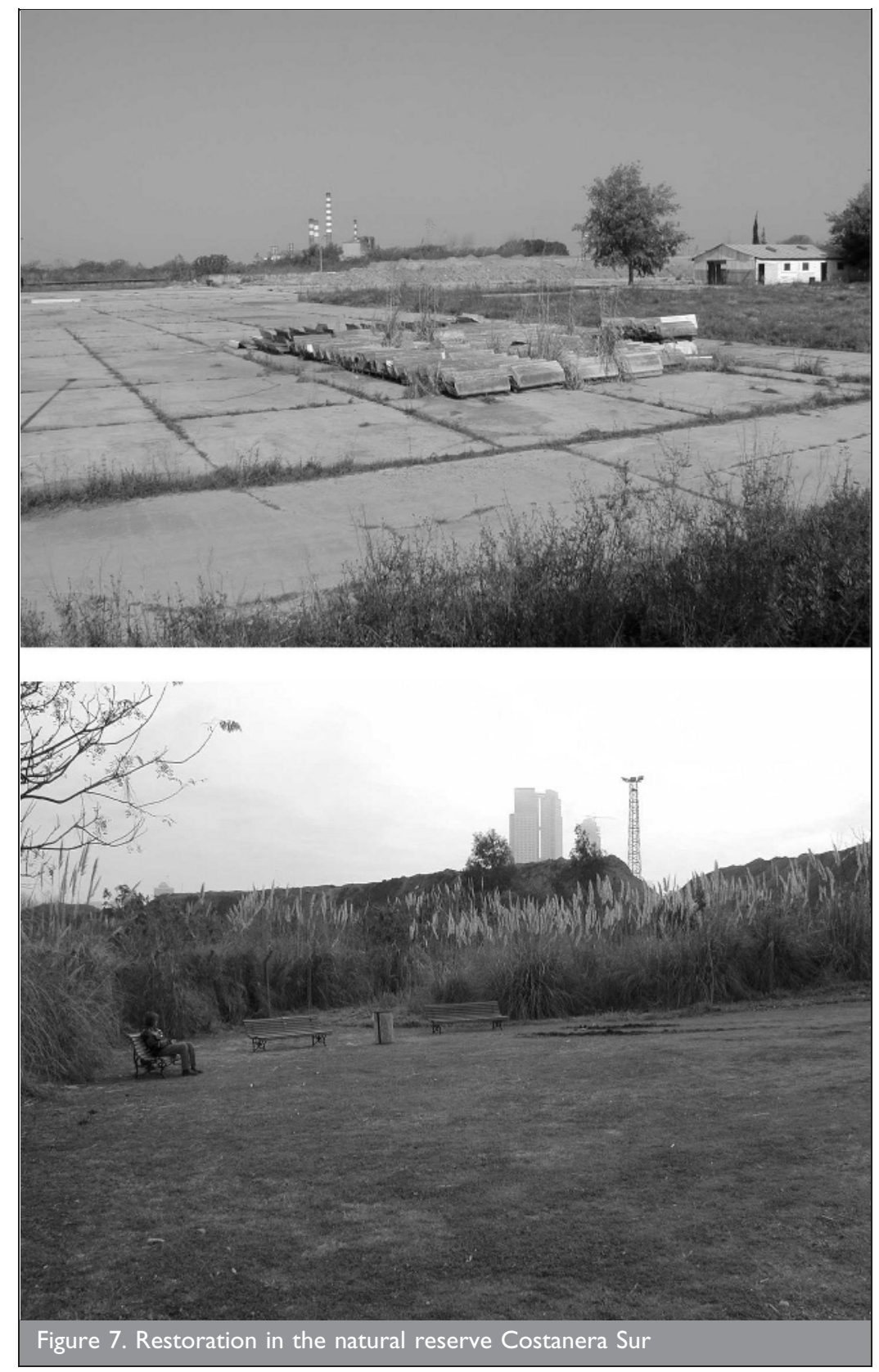

and collaboration. Examples of watershed ecosystem management in Hawaii, Asia, Africa and USA (Gutrich et al. 2005) point out that a partnership generates a better policy to increase public awareness and mobilise support. Public opinion can help to refine goals and strategies. The interaction between proponents, stakeholders and planners should come as early as possible.

Many indicators show that the regeneration of the waterfront has been successful in making a more amenable Buenos Aires.

The commitment to enhance the quality of life has been a major factor in attracting investors to develop diverse commercial activities, particularly focused on retailing. Ten kilometres of the coastal green corridor adds a significant public space for recreation, sport and landscape enjoyment.

Buenos Aires, being the most important Argentine city and the first tourist destination of the country, benefits from a highquality physical and green environment. This is the reason why the neighbourhood of Puerto Madero is the second most preferred tourist destination.
The waterfront has become a city icon by offering a panoply of activities related to the appreciation of the city's cultural heritage, the conservation of its remaining natural landscapes and the promotion of leisure. These have been the drivers behind the city's current image of modernity. This image could not have been attained without a strong societal desire for change, and the political willingness of the public sector to engage the participation of citizens in the resolution of conflicts and satisfying the neighbours demands for effective urban environmental planning.

\section{CONCLUSION}

As indicated in this article, co-management was a useful tool to support vital ecological processes in the renewal of the Buenos Aires waterfront. This process started after democracy returned two decades ago and, thanks to the initiative of citizens, that was successful in the integrative collaboration of local government, urban designers, NGOs, ecologists and several and sundry stakeholders. Currently the city administration supports the programme initiated many years ago. Its coastal management department carries out adaptive management actions in 


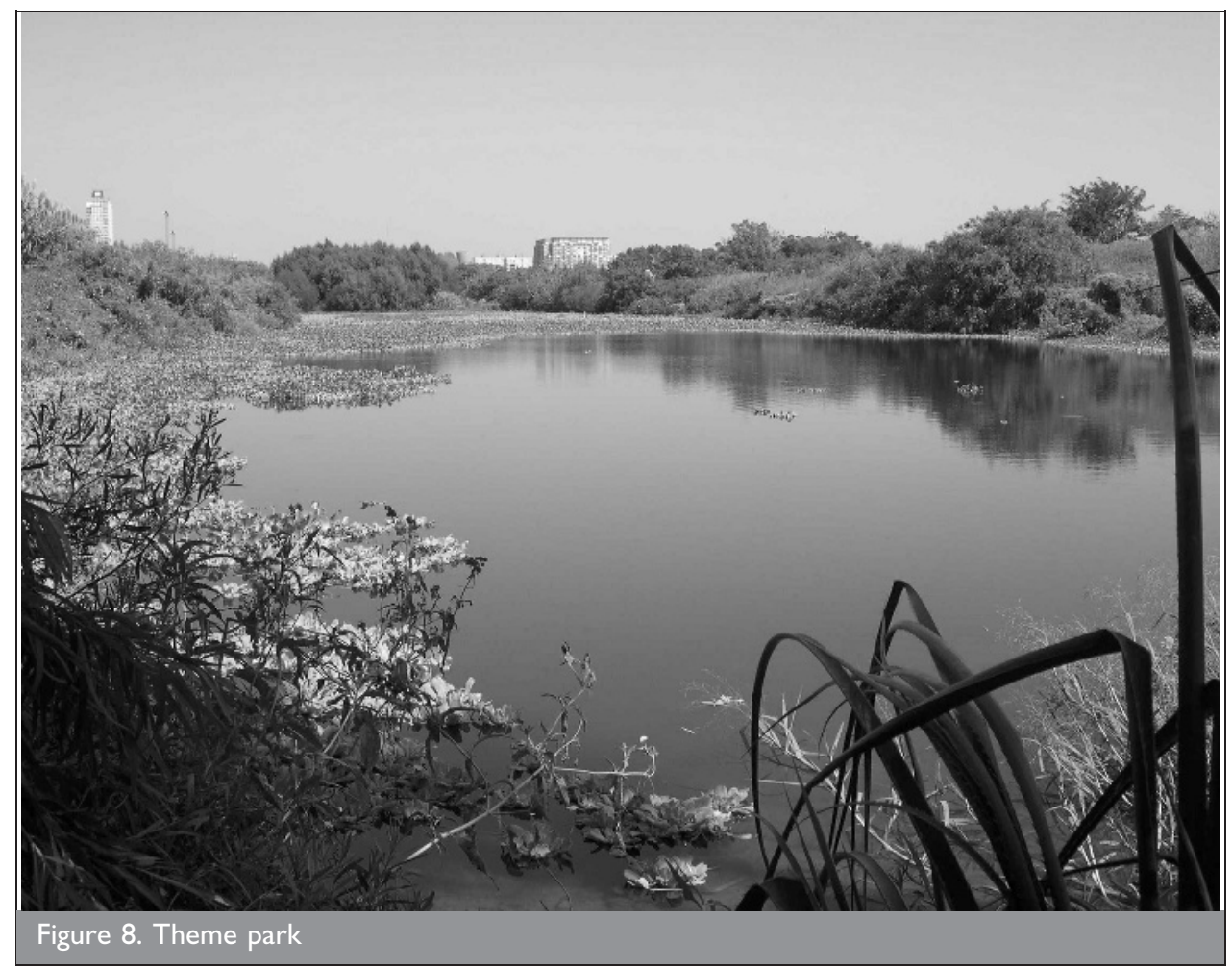

close association with a collection of users, analysts, facilitators and agents who have diverging interests and political leverage.

As such, the Buenos Aires example can be considered to be part of a 'good governance' exercise through multilayered participation, representation, deliberation, empowerment and social justice. Therefore it is expected that, in the future, policies for the waterfront could be carried out continuously by comanagement between government and stakeholders, and be immune to the vagaries of political partisanship.

\section{REFERENCES}

Aguilar M, Castellanos J, Novoa G, Zito F and Wagner A (2005) La ribera de la ciudad de Buenos Aires: entre la parálisis y el desconcierto. In Buenos Aires a la deriva (Welch Guerra M (ed.)). Biblos, Buenos Aires, pp. 168-202.

Brody SD, Highfield W and Carrasco V (2004) Measuring the collective planning capabilities of local jurisdiction to manage systems in southern Florida. Landscape and Urban Planning 69(1): 33-50.

Brown RA and Harris G (2005) Co-management of wildlife corridors: the case for citizen participation in the Algonquin to Adirondack proposal. Journal of Environmental Management 74: 97-106.

Bunce S and Desfor G (2007) Introduction to political ecologies of urban waterfront transformations. Cities 24(4): 251-258.

Busquets J (1995) Planeamiento: pasado reciente y futuro próximo. Sociedade e Território. Revista de Estudos Urbanos e Regionais 22: 9-21.

Cowell R and Thomas H (2002) Managing nature and narratives of dispossession: reclaiming territory in Cardiff Bay. Urban Studies 39(7): 1241-1260.

Fundación Ciudad (2007) La ribera sur. Fundacion Ciudad, Buenos Aires.

Gospodini A (2006) Portraying, classifying and understanding the emerging landscapes in the post-industrial city. Cities 23(5): 311-360.
Gutrich J, Donovan D, Finucane M, et al. (2005) Science in the public process of ecosystem management: lessons from Hawaii, Southeast Asia, Africa and the US Mainland. Journal of Environmental Management 76(3): 197-209.

Higgs ES (1997) What is good ecological restoration? Conservation Biology 11: 338-348.

Innes J (1996) Planning through consensus building: a new view of the comprehensive planning ideal. Journal of the American Planning Association 62(4): 460-472.

Janoschka M (2002) El nuevo modelo de la ciudad latinoamericana: fragmentación y privatización. EURE 28(85): 11-20.

Jauhiainen J (1995) Waterfront redevelopment and urban policy: the case of Barcelona, Cardiff and Genoa. European Studies 3(1): 3-21.

Kennedy DS, McAllister ST, Caile WH and Peckham JS (2000) The New Watershed Source Book. Natural Resources Law Center, University of Colorado School of Law, Boulder, CO.

Krellenberg K, Faggi AM and Endlicher W (2005) Umweltpolitik in Argentinien - dargestellt am Beispiel des Flusses Riachuelo/Río Matanza in Buenos Aires im Vergleich zur Emscher im Ruhrgebiet. GEOÖKO 26: 19-34.

Lane MB (2001) Affirming new directions in planning theory: co-management of protected areas. Society and Natural Resources 14: 657-671.

Mann RB (1988) Ten trends in the continuing renaissance of urban waterfronts. Landscape and Urban Planning 16(1-2): 177-199.

McCarthy J (2002) Encouraging culture-led regeneration. Proceedings of a Conference on Urban and Spatial European Policies: Levels of Territorial Government, Turin, p. 12.

McCarthy J (2003) Spatial planning, tourism and regeneration in historic port cities. DISP 154(19). See www.nsl.cthz.ch/ index.php/en/content/download/459/3015/file.

Olsson P, Folke C and Hahn T (2004) Social-ecological transformation for ecosystem management: the development of adaptive co-management of a wetland landscape in 
Southern Sweden. Ecological Society 9(2). See http://www. ecologyandsociety.org/vol9/iss4/art2.

Pfadenhauer J (2001) Some remarks on the socio-cultural background of restoration ecology. Restoration Ecology 9: 220-229.

Richardson DM, Holmes PM, Esler KJ, et al. (2007) Riparian vegetation: degradation, alien plant invasions, and restoration prospects. Diversity and Distributions 13: 126-139.

Sairinen R and Kumpulainen S (2006) Assessing social impacts in urban waterfront regeneration. Environmental Impact Assessment Review 26(1): 120-135.

Torres HA (2001) Cambios socio-territoriales en Buenos Aires durante la década de 1990. EURE 27(80): 33-56.

van Diggelen R, Grootjans AP and Harris JA (2001) Ecological restoration: state of the art or state of the science? Restoration Ecology 9(2): 115-118.

Walters C and Holling CS (1990) Large-scale management experiments and learning by doing. Ecology 71(6): 20602068.

Walters CJ (1997) Challenges in adaptive management of riparian and coastal ecosystems. Conservation Ecology 1(2). See 1 http://www.concecol.org/vol1/iss2/art1.

Wang MS and Fang JK (2000) An integrated framework for public sector environmental management in developing countries. Environmental Management 25(5): 463-476.

Yáñez-Arancibia A and Day JW (2004) The Gulf of Mexico: towards an integration of coastal management with large marine ecosystem management. Ocean and Coastal Management 47(11-12): 537-563.

\section{What do you think?}

To discuss this paper, please email up to 500 words to the editor at journals@ice.org.uk. Your contribution will be forwarded to the author(s) for a reply and, if considered appropriate by the editorial panel, will be published as discussion in a future issue of the journal.

Proceedings journals rely entirely on contributions sent in by civil engineering professionals, academics and students. Papers should be 2000-5000 words long (briefing papers should be 1000-2000 words long), with adequate illustrations and references. You can submit your paper online via www.icevirtuallibrary.com/content/journals, where you will also find detailed author guidelines. 